\title{
PEMBERIAN BERBAGAI PUPUK ORGANIK TERHADAP PERTUMBUHAN DAN PRODUKSI BEBERAPA VARIETAS PADI GOGO (Oryza sativa L.) YANG DITANAM DIANTARA TANAMAN KELAPA SAWIT BELUM MENGHASILKAN
}

\section{The Provision of Variety Organic Fertilizer on the Growth and Yield of Several Varieties of Upland Rice (Oryza sativa L.)which Planted among Immature Oil Palm Trees}

\author{
Fetmi Silvina,Arnis en Yulia, Noreza Masri \\ Departement of Agroteknologi, Faculty of Agriculture, University of Riau \\ Email: fetmisilvina@gmail.com (081275567108) \\ [Diterima: Mei 2017 ; Disetujui: Oktober 2017]
}

\begin{abstract}
The study aimed to determine the effect of various organic fertilizers on growth and yield of several varieties of upland rice, and the response of upland rice varieties to organic fertilizers under the stands of oil palm trees have not produced (TBM). The researches conducted in March until July 2016. This study was a randomized block design factorial trial with two factors and three replications, the first factor was some upland rice variety consist of ; Inpago 8 (V1), Situ Bagendit (V2), and Inpago 9 (V3) and the second factor was the variety of organic fertilizers such as; without organic fertilizer (BO0), compost of oil palm empty fruit bunches (BO1), chicken manure (BO2), Kirinyuh or green manure (BO3). Data were analyzed by ANOVA and a further test of Duncan's multiple range test (DNMRT) level of 5\%. The results showed that the varieties Situ Bagendit gave the best response to organic fertilizer by weight of dry milled grain at 4.6 tonnes/ha in the giving of chicken manure.
\end{abstract}

Keywords: Upland rice, Variety, Organic fertilizer

\begin{abstract}
ABSTRAK
Penelitian ini bertujuan untuk mengetahui pengaruh berbagai pupuk organik terhadap pertumbuhan dan hasil beberapa varietas padi gogo, dan respon varietas padi gogo terhadap pupuk organik di bawah tegakan pohon kelapa sawit belum menghasilkan (TBM). Penelitian dilakukan pada bulan Maret hingga Juli 2016. Penelitian ini merupakan penelitian acak rancangan faktorial dengan dua faktor dan tiga ulangan, faktor pertama adalah beberapa varietas padi gogo yang terdiri dari; Inpago 8 (V1), Situ bagendit (V2), dan Inpago 9 (V3) dan faktor kedua adalah varietas pupuk organik seperti; tanpa pupuk organik (BO0), kompos tandan kosong kelapa sawit (BO1), kotoran ayam (BO2), kirinyuh atau pupuk hijau (BO3). Data dianalisis dengan ANOVA dan uji lebih lanjut tingkat uji rentang ganda Duncan (DNMRT) 5\%. Hasil penelitian menunjukkan bahwa varietas Situ Bagendit memberikan respons terbaik terhadap pupuk organik berdasarkan berat kering gabah kering sebesar 4,6 ton / ha dalam pemberian kotoran ayam.
\end{abstract}

Kata kunci: Padi gogo, Varietas, Pupuk organik

\section{PENDAHULUAN}

Padi (Oryza sativa L.) merupakan tanaman penghasil beras merupakan bahan makanan pokok penduduk Indonesia. Produksi padi saat ini masih bertumpu pada lahan sawah beririgasi, namun beberapa tahun terakhir telah banyak terjadi alih fungsi lahan sawah produktif menjadi nonproduktif, sehingga menurunkan produksi padi, oleh karena itu pengembangan padi gogo menjadi salah satu alternatif untuk meningkatkan produksi beras. 
Tanaman padi merupakan tanaman C3 yang masih dapat meningkatkan pertumbuhannya pada lingkungan yang ternaungi, sehingga dapat dibudidayakan secara tumpang sari dan tanaman sela di bawah tegakan tanaman industri, seperti tanaman kelapa sawit.

Provinsi Riau merupakan salah satu daerah pengembangan tanaman kelapa sawit terluas di Indonesia, sehingga pemanfaatan lahan diantara tanaman kelapa sawit yang belum menghasilkan dapat dijadikan lahan untuk penanaman padi gogo. Tanaman kelapa sawit di Provinsi Riau umumnya ditanam pada lahan gambut dan mineral. Penanaman kelapa sawit di lahan mineral didominasi oleh tanah inceptisol yang memiliki banyak permasalahan seperti $\mathrm{pH}$ tanah rendah, kandungan bahan organikrendah, dan kekeringan, sehingga perlu dilakukan upaya untuk memperbaikinya, denganpenambahan bahan organik. Beberapa bahan organik yang dapat digunakan adalah kompos tandan kosong kelapa sawit (TKKS), pupuk hijau kirinyuh dan pupuk kandang ayam.

Pupuk organik berperan dalam memperbaiki sifat fisik, kimia dan biologi tanah, sehingga dapat mendukung pertumbuhan dan perkembangan tanah. Secara fisik bahan organik memperbaiki struktur, meningkatkan porositas tanah, daya pegang air tanah, memperbaiki aerasi dan drainasi tanah. Perbaikan sifat kimia adalah meningkatkan $\mathrm{pH}$ tanah, kapasitas pertukaran kation, dan ketersediaan unsur hara, sedangkan perbaikan sifat biologi adalah meningkatkan aktivitas mikroorganisme.

Saat ini sudah dihasilkan beberapa varietas tanaman padi gogo yang mempunyai sifat toleran terhadap $\mathrm{Al}$ dan $\mathrm{Fe}$ dan cocok ditanam di lahan kering. Varietas-varietas tersebut perlu diuji kemampuannya untuk tumbuh dan menghasilkan pada lahan di bawah tegakan tanaman kelapa sawit yang diberi pupuk organik.

Berdasarkan permasalahan yang dikemukakan telah dilakukan penelitian yang berjudul "Pemberian berbagai pupuk organik terhadap pertumbuhan dan produksi beberapa varietas padi gogo (Oryza sativa L.) yang ditanam diantara tanaman kelapa sawit belum menghasilkan".

Penelitian ini bertujuan untuk mengetahui pengaruh pemberian berbagai pupuk organik terhadap pertumbuhan dan produksi beberapa varietas padi gogo, serta respon varietas padi gogo terhadap pemberian pupuk organik di bawah tegakan tanaman kelapa sawit belum menghasilkan (TBM) berumur 3 tahun.

\section{BAHAN DAN METODE}

Penelitian ini dilaksanakan di kebun percobaan Fakultas Pertanian Universitas Riau yang berada di areal Stadion Utama Riau di Kampus Binawidya Km 12,5 Pekanbaru dari bulan Maret sampai Juli 2016.

Bahan yang digunakan dalam penelitian ini adalah benih padi gogo varietas unggul yang terdiri dari 3 verietas, yaitu varietas Inpago 9, Situ Bagendit, dan Inpago 8. Kompos Tandan Kosong Kelapa Sawit (TKKS), pupuk Urea, TSP, $\mathrm{KCl}$ (diberikan $1 / 2$ dosis anjuran sebagai sumber $\mathrm{N}, \mathrm{P}$ dan $\mathrm{K}$ ), kapur dolomit, pupuk kandang ayam, pupuk hijau kirinyuh, furadan, pestisida Reagent 50 SC (Bahan aktif Fipronil $50 \mathrm{~g} / \mathrm{l}$ ), insektisida Sevin 35 SP.

Alat yang digunakan adalah oven listrik, handsprayer, timbangan digital, timbangan analitik, jaring, $\mathrm{pH}$ meter, mistar, cangkul, gembor, kertas label, termometer tanah, ombrometer, higrometer, lux meter, ajir, pisau, parang, plastik, ember, tali rafia, wadah, karung, kamera dan alat tulis.

Penelitian ini merupakan percobaan faktorial yang terdiri dari 2 faktor yang disusun menurut Rancangan Acak Kelompok (RAK). Faktor I : Varietas padi gogo, yang terdiri dari 3 taraf yaitu $\mathrm{V}_{1}=$ Inpago $8, \mathrm{~V}_{2}=$ Situ Bagendit $\mathrm{V}_{3}$ $=$ Inpago 9, Faktor II : Pemberian bahan organik yang terdiri dari 4 taraf perlakuan yaitu : $\mathrm{BO}_{0}=$ Tanpa perlakuan, $\mathrm{BO}_{1}=$ Pemberian kompos TKKS 10 ton/ha $(2,25$ $\mathrm{kg} / \mathrm{plot}), \mathrm{BO}_{2}=$ Pemberian pupuk kandang ayam (Pukan ayam) 10 ton/ha $(2,25 \mathrm{~kg} / \mathrm{plot})$, $\mathrm{BO}_{3}=$ Pemberian pupuk hijau kirinyuh 10 ton/ha $(2,25 \mathrm{~kg} / \mathrm{plot})$. Dari kedua faktor tersebut diperoleh 12 kombinasi perlakuan yang diulang sebanyak 3 kali, sehingga diperoleh 36 satuan percobaan.

Parameter yang diamati tinggi tanaman, jumlah anakan maksimum, umur keluar malai, jumlah anakan produktif, berat gabah bernas, persentase gabah bernas, berat 1000 biji dan berat gabah kering giling. 
Data dari hasil sidik ragam diuji lanjut dengan uji jarak berganda Duncan taraf 5\%.

\section{Hasil dan Pembahasan \\ Kondisi Umum Lokasi Penelitian}

Tabel 1 dan 2. Tabel 1. Hasil analisis pH tanah

\begin{tabular}{lcc}
\hline \multicolumn{1}{c}{ Perlakuan } & $\mathrm{pH}$ awal & $\mathrm{pH}$ setelah penelitian \\
\hline TKKS & 5,3 & 5,52 \\
Pukan Ayam & 5,3 & 5,63 \\
Kirinyuh & 5,3 & 5,80 \\
\hline
\end{tabular}

Laboratorium Tanah Fakultas Pertanian Universitas Riau

Tabel 2. Hasil analisis kimia tanah di lahan sawit Fakultas Pertanian Universitas Riau.

\begin{tabular}{lc}
\hline Kimia Tanah & Hasil Analisis \\
\hline C-Organik (\%) & 0,67 \\
Bahan Organik (\%) & 1,14 \\
KTK (me/100g) & 14,38 \\
Kejenuhan Basa (\%) & 9,10 \\
Al dd (me/100g) & 3,20 \\
\hline
\end{tabular}

Laboratorium tanah fakultas pertanian Universitas Riau 2016

Kandungan bahan organik dan C-organik tanah sebelum pemberian pupuk organik tergolong rendah masing-masing $1,14 \%$ dan $0,67 \%$. Hal ini menunjukkan bahwa lahan penelitian membutuhkan penambahan bahan organik untuk meningkatkan kemampuan tanah mengikat air sehingga air tersedia bagi tanaman. Kapasitas Tukar Kation (KTK) tanah tergolong sedang yaitu $14,38 \%$, KTK tanah pada umumnya tergantung pada muatan negatif yang berada pada koloid jerapan, kation-kation $\mathrm{Mg}, \mathrm{Ca}, \mathrm{K}$ dan $\mathrm{Na}$ dari koloid jerapan ditukar oleh ion-ion $\mathrm{H}^{+}$sehingga ion-ion $\mathrm{H}^{+}$yang
Hasil analisis tanah di lahan kelapa sawit Fakultas Pertanian Universitas Riau sebelum dan setelahpenelitian dapat dilihat pada

Tabel 3. Data Cuaca Selama Penelitian

\begin{tabular}{lcrrrrrrr}
\hline Bulan & $\begin{array}{c}\text { Curah } \\
\text { Hujan } \\
(\mathrm{mm})\end{array}$ & \multicolumn{2}{c}{ Kelembaban $(\%)$} & & \multicolumn{2}{c}{ Suhu $\left({ }^{\circ} \mathrm{C}\right)$} & $\begin{array}{r}\text { Cahaya } \\
\text { Matahari } \\
\left(\mathrm{kal} / \mathrm{cm}^{2}\right)\end{array}$ & $\begin{array}{r}\text { Tingkat } \\
\text { Naungan } \\
(\%)\end{array}$ \\
\hline April & 158,44 & 60 & 52 & 24,0 & 36,2 & 678 & 7 \\
Mei & 103,60 & 54 & 49 & 22,7 & 36,1 & 563,3 & 10 \\
Juni & 56,40 & 52 & 45 & 22,5 & 35,5 & 1.043 & 4 \\
Juli & 40,60 & 60 & 54 & 22,2 & 35,8 & 1.118 & 6,3 \\
\hline Rata-rata & 89,76 & 56 & 50 & 22,7 & 36,0 & 850,575 & 8,82 \\
\hline
\end{tabular}

Suhu udara rata-rata selama penelitian yaitu pagi $22,7^{\circ} \mathrm{C}$ dan siang $36^{\circ} \mathrm{C}$, suhu selama penelitian tergolong tinggi, namun masih dapat digunakan untuk budidaya padi gogo. Yoshida (1981) menyatakan bahwa suhu kritis untuk pertumbuhan tanaman padi gogo yaitu di bawah $20^{\circ} \mathrm{C}$ dan di atas $35^{\circ} \mathrm{C}$, suhu kritis mendominasi kompleks jerapan. Menurut Onky (2014) kapasitas tukar kation juga tergantung pada $\mathrm{pH}$ tanah, pada $\mathrm{pH} 7$ tanah yang sedikit mengalami dekomposisi mempunyai KTK sebesar $100 \mathrm{cmol} / \mathrm{kg}$

Pertumbuhan dan perkembangan tanaman padi gogo di bawah tegakan sawit selain ditentukan oleh tanah dan lingkungan tumbuhnya ditentukan juga oleh faktor cuaca. Selama penelitian dilakukan pengamatan terhadap beberapa komponen cuaca dan disajikan pada Tabel 3 . tersebut bervariasi menurut varietas, lamanya suhu kritis berlangsung, perubahan suhu harian siang dan malam, serta kondisi fisiologi tanaman padi itu sendiri, pertumbuhan tanaman padi gogo membutuhkan suhu udara $20-30^{\circ} \mathrm{C}$. 
Curah hujan rata-rata selama penelitian (bulan April-Juli 2016) yaitu 89,76 mm/bulan dengan jumlah hari hujan yaitu 21 hari, sehingga curah hujan selama penelitian dapat dikatakan sangat rendah dan di bawah syarat tumbuh yang dibutuhkan untuk pertumbuhan padi gogo.Menurut penelitian Oldeman dan Frere (1982), agar padi gogo dapat tumbuh dengan baik diperlukan curah hujan dalam sebulan minimal $200 \mathrm{~mm}$.Kelembaban udara rata-rata pagi hari $56 \%$ dan siang hari $50 \%$. Intensitas cahaya matahari rata-rata selama penelitian $850,57 \mathrm{kal} / \mathrm{cm}^{2}$. Intensitas cahaya yang dibutuhkan untuk produksi padi gogo maksimum adalah $400 \mathrm{kal} / \mathrm{cm}^{2}$ pada fase pertumbuhan vegetatif dan $475 \mathrm{kal} / \mathrm{cm}^{2}$ pada fase pengisian dan pemasakan (Yoshida dan Parao, 1976). Selama penelitian intensitas cahaya matahari di lapangan tergolong tinggi dan tingkat naungan pada sawit TBM 3 masih rendah, sehingga tanaman padi masih dapat tumbuh dan berproduksi dengan baik. Pertumbuhan dan produksi padi gogo pada taraf naungan 50\% dengan intensitas cahaya $120.5 \mathrm{kal} / \mathrm{cm}^{2}$ akan bervariasi sehingga terlihat adanya galur toleran, moderat dan peka (Haris, 1999).

Tabel 4. Pengukuran Kadar Air Tanah Selama Penelitian (\%)

\begin{tabular}{cccccc}
\hline Kedalaman & Pengamatan & $\begin{array}{c}\text { Tanpa } \\
\text { perlakuan }\end{array}$ & $\begin{array}{c}\text { Kompos } \\
\text { TKKS }\end{array}$ & Pukan ayam & kirinyuh \\
\hline $0-10 \mathrm{~cm}$ & 1 & 17,45 & 17,00 & 17,28 & 18,20 \\
& 2 & 16,46 & 18,14 & 18,92 & 18,25 \\
\multirow{3}{*}{$10-20 \mathrm{~cm}$} & 3 & 16,00 & 18,04 & 19,06 & 19,00 \\
& 1 & 30,24 & 32,30 & 32,20 & 30,61 \\
& 2 & 29,60 & 31,06 & 33,96 & 30,16 \\
\hline Rata-rata & 3 & 28,00 & 32,04 & 36,77 & 31,16 \\
\hline
\end{tabular}

Laboratorium Fakultas Pertanian Universitas Riau (2016)

Tabel 4 menunjukkan bahwa rata-rata kadar air tanah berbeda pada setiap pemberian pupuk organik, perlakuan yang diberi pupuk organik (pukan ayam, kompos TKKS dan kirinyuh) mampu meningkatkan kadar air dalam tanah dibandingkan dengan tanpa bahan organik. Pukan ayam merupakan pupuk organik yang mampu menghasilkan rata-rata persentase kadar air tanah (kedalaman tanah 0$20 \mathrm{~cm}$ ) yang lebih tinggi yaitu 26,36\%. Hal ini menunjukkan bahwa pemberian pupuk organik mampu meningkatkan kemampuan memegang air sehingga air dan unsur hara tersedia bagi tanaman.

Berdasarkan hasil analisis laboratorium Fakultas Pertanian Universitas Riau (2016) kandungan $\mathrm{C} / \mathrm{N}$ dari pukan ayam lebih tinggi dibandingkan dua jenis pupuk organik TKKS dan kirinyuh.

Sesuai pendapat Sarief (1989) bahwa dengan meningkatnya daya pegang tanah terhadap air akibat pemberian bahan organik maka akan meningkatkan pula volume air yang terkandung dan tersimpan dalam tanah yang berarti meningkatkan air tersedia bagi tanaman. Rumiati et al. (1982) menyatakan bahwa batas minimal kadar air tanah untuk pertumbuhan padi gogo adalah $25 \%$.

Menurut penelitian Tejasuwarna (1999) bahwa penambahan pupuk kandang ayam di tanah Andisol mampu meningkatkan pori memegang air sebesar 4,73\% (dari 69,8\% menjadi $73.1 \%$ ). Sarief (1986) menyatakan bahwa pemberian bahan organik yang berasal dari pupuk kandang dan kompos pada tanah dengan tekstur liat dapat meningkatkan kadar air tanah dan kapasitas air tersedia serta dapat menurunkan berat volume tanah.

\section{Tinggi Tanaman}

Hasil sidik ragam menunjukkan bahwa beberapa varietas padi gogo dan pemberian berbagai pupuk organik berpengaruh nyata terhadap tinggi tanaman padi. Hasil uji jarak berganda Duncan taraf 5\% dapat dilihat pada Tabel 5. 
Tabel 5. Tinggi Tanaman Beberapa Varietas Padi Gogo pada Pemberian Berbagai Pupuk Organik

\begin{tabular}{lcccc}
\hline \multicolumn{1}{c}{ Pupuk Organik } & \multicolumn{3}{c}{ Varietas Padi Gogo } & Rata-rata \\
\cline { 2 - 3 } \multicolumn{1}{c}{ (10 ton/ha) } & Inpago 8 & Situ Bagendit & Inpago 9 & \\
Tanpa Perlakuan & $89,33 \mathrm{ab}$ & $59,11 \mathrm{~d}$ & $60,22 \mathrm{~d}$ & $69,55 \mathrm{c}$ \\
Kompos TKKS & $102,44 \mathrm{a}$ & $65,77 \mathrm{~cd}$ & $95,44 \mathrm{a}$ & $79,25 \mathrm{~b}$ \\
Pukan Ayam & $104,22 \mathrm{a}$ & $65,55 \mathrm{~cd}$ & $98,33 \mathrm{a}$ & $89,37 \mathrm{a}$ \\
Kirinyuh & $94,66 \mathrm{ab}$ & $64,33 \mathrm{~cd}$ & $78,77 \mathrm{bc}$ & $87,88 \mathrm{ab}$ \\
\hline Rata-rata & $97,66 \mathrm{a}$ & $63,69 \mathrm{c}$ & $83,19 \mathrm{~b}$ &
\end{tabular}

Angka-angka pada kolom dan baris yang diikuti huruf kecil yang sama berbeda tidak nyata menurut uji jarak berganda Duncan taraf 5\%.

Tabel 5 menunjukkan bahwa Varietas Inpago 8 merupakan varietas yang memiliki tinggi tanaman lebih tinggi yang tidak berbeda nyata dengan varietas Inpago 9 dan berbeda nyata dengan varietas Situ Bagendit. Pemberian kompos TKKS dan pukan ayam menghasilkan tinggi tanaman tertinggi pada varietas Inpago 8 dan Inpago 9. Hal ini menunjukkan bahwa varietas Inpago 8 dan Inpago 9 mempunyai karakteristik tinggi tanaman yang lebih tinggi dibandingkan dengan varietas Situ Bagendit.

Pemberian pukan ayam menghasilkan tinggi tanaman yang lebih tinggi dan berbeda nyata dengan tanpa pemberian perlakuan dan kompos TKKS.

Nyakpa et al.(1988) menyatakan bahwa setiap varietas memiliki respon yang berbeda terhadap kondisi lingkungan yang berbeda. Pemberian pupuk organik dapat memperbaiki kondisi tanah, diantaranya struktur tanah menjadi gembur, daya pegang air meningkat dan unsur hara tanah menjadi tersedia. Pemberian bahan organik yang secara nyata dapat meningkatkan tinggi tanaman adalah pukan ayam. Pukan ayam selain mengandung bahan organik yang tinggi, juga mengandung unsur hara seperti nitrogen dan phosfat yang lebih tinggi dibandingkan pupuk kandang yang lain (Lingga, 1991).

\section{Jumlah Anakan Maksimum}

Hasil sidik ragam menunjukkan bahwa pemberian berbagai pupuk organik berpengaruh tidak nyata terhadap jumlah anakanmaksimum, sedangkan beberapa varietas padi gogo berpengaruh nyata terhadap jumlah anakan maksimum. Hasil uji jarak berganda Duncan taraf 5\% dapat dilihat pada Tabel 6.

Tabel 6. Jumlah Anakan Maksimum Beberapa Varietas Padi Gogo padaPemberian Berbagai Pupuk Organik

\begin{tabular}{|c|c|c|c|c|}
\hline \multirow{2}{*}{$\begin{array}{c}\text { Pupuk Organik } \\
\text { (10 ton/ha) }\end{array}$} & \multicolumn{3}{|c|}{ Varietas Padi Gogo } & \multirow[t]{2}{*}{ Rata-rata } \\
\hline & Inpago 8 & Situ Bagendit & Inpago 9 & \\
\hline \multicolumn{5}{|c|}{ 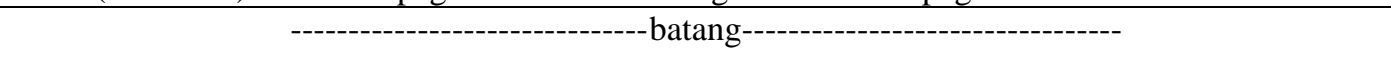 } \\
\hline Tanpa Perlakuan & $16,43 \mathrm{bcd}$ & $23,66 \mathrm{ab}$ & $11,43 \mathrm{~d}$ & $17,17 \mathrm{a}$ \\
\hline Kompos TKKS & $15,00 \mathrm{~cd}$ & $24,66 a b$ & $15,23 \mathrm{~cd}$ & $18,30 \mathrm{a}$ \\
\hline Pukan Ayam & $17,33 \mathrm{bcd}$ & $22,43 a b c$ & $20,33 a b c$ & $20,03 \mathrm{a}$ \\
\hline Kirinyuh & $17,66 \mathrm{bcd}$ & $28,33 \mathrm{a}$ & $17,76 \mathrm{bcd}$ & $21,25 \mathrm{a}$ \\
\hline Rata-rata & $16,60 \mathrm{~b}$ & $24,77 \mathrm{a}$ & $16,19 b$ & \\
\hline
\end{tabular}

Angka-angka pada kolom dan baris yang diikuti huruf kecil yang sama berbeda tidak nyata menurut uji jarak berganda Duncan taraf 5\%

Tabel 6 menunjukkan bahwa varietas Situ Bagendit menghasilkan jumlah anakan maksimum tertinggi dan berbeda nyata dengan dua varietas uji lainnya pada pemberian berbagai pupuk organik, sedangkan perlakuan pupuk organik tidak memberikan pengaruh yang nyata terhadap jumlah anakan maksimum. Jumlah anakan maksimum varietas Situ bagendit mencapai 24.77 anakan, hal ini diduga bahwa varietas Situ Bagendit 
mempunyai genetik yang mampu beradaptasi pada lingkungan tempat penelitian dengan menghasilkan jumlah anakan maksimum yang lebih banyak. Menurut data Pusat Penelitian dan Pengembangan Tanaman Pangan Bogor (2011) varietas Situ Bagendit merupakan varietas unggul yang sagat cocok ditanam di lahan kering.

\section{Umur Keluar Malai}

Hasil sidik ragam menunjukkan bahwa beberapa varietas padi gogo dan pemberian berbagai pupuk organik berpengaruh nyata terhadap umur keluar malai.Hasil uji jarak berganda Duncan taraf 5\% dapat dilihat pada Tabel 7.

Tabel 7. Umur Keluar Malai Beberapa Varietas Padi Gogo pada Pemberian Berbagai Pupuk organik

\begin{tabular}{lllll}
\hline \multicolumn{1}{c}{$\begin{array}{c}\text { Pupuk Organik } \\
\text { (10 ton/ha) }\end{array}$} & \multicolumn{3}{c}{ Varietas Padi Gogo } & Rata-rata \\
\cline { 2 - 3 } & Inpago 8 & Situ Bagendit & Inpago 9 & \\
Tanpa Perlakuan & $-94,66 \mathrm{f}$ & $82,33 \mathrm{ef}$ & $89,66 \mathrm{f}$ & $88,88 \mathrm{c}$ \\
Kompos TKKS & $88,00 \mathrm{ef}$ & $75,33 \mathrm{bc}$ & $79,66 \mathrm{ed}$ & $81,00 \mathrm{~b}$ \\
Pukan Ayam & $82,33 \mathrm{ef}$ & $73,56 \mathrm{ab}$ & $72,56 \mathrm{a}$ & $76,22 \mathrm{a}$ \\
Kirinyuh & $87,33 \mathrm{ef}$ & $76,00 \mathrm{~cd}$ & $75,00 \mathrm{ef}$ & $79,44 \mathrm{~b}$ \\
\hline Rata-rata & $88,08 \mathrm{~b}$ & $76,83 \mathrm{a}$ & $79,25 \mathrm{~b}$ & \\
\hline
\end{tabular}

Angka-angka pada kolom dan baris yang diikuti huruf kecil yang sama berbeda tidak nyata menurut uji jarak berganda Duncan taraf 5\%

Tabel 7 menunjukkan bahwa umur keluar malai varietas Situ Bagendit lebih cepat dibandingkan kedua varietas uji lainnya yaitu 76,83 hari dan berbeda nyata dengan varietas Inpago 8 dan Inpago 9. Pemberian pupuk organik pukan ayam menunjukkan rata-rata umur keluar malai tercepat yaitu 76,22 hari. Hal ini diduga bahwa varietas Situ Bagendit dan Inpago 9 merupakan varietas yang mampu tumbuh dengan baik pada lahan kering dan suhu yang tinggi. Data pengamatan suhu ratarata fase pembungaan cukup tinggi $32,5^{\circ} \mathrm{C}$. Secara umum batas kritis suhu rendah dan tinggi masing-masing di bawah $20^{\circ} \mathrm{C}$ dan di atas $30^{\circ} \mathrm{C}$ (Yoshida, 1981).

Pemberian pupuk organik mempengaruhi umur keluar malai, dimana pemberian pukan ayam menunjukkan umur keluar malai lebih cepat dan berbeda nyata dengan pemberian bahan organik lainnya. Bahan organik yang terkandung pada pupuk kandang ayam yang diaplikasikan dapat meningkatkan $\mathrm{pH}$ tanah (Tabel 1) dan menambah ketersediaan unsur hara di dalam tanah seperti unsur $\mathrm{P}$ yang kemudian akan diserap melalui akar tanaman dan dimanfaatkan untuk pembentukan bunga. Unsur $\mathrm{P}$ yang terkandung dalam pupuk kandang ayam peranannya sangat penting untuk pertumbuhan dan perkembangan tanaman. Soepardi (1983) menyatakan bahwa peranan $\mathrm{P}$ untuk pertumbuhan sel, pembentukan akar, bunga, buah dan biji.

\section{Jumlah Anakan Produktif}

Hasil sidik ragam menunjukkan bahwa beberapa varietas padi gogo berpengaruh nyata terhadap jumlah anakan produktif sedangkan pemberian berbagai pupuk organik berpengaruh tidak nyata terhadap jumlah anakan produktif. Hasil uji jarak berganda Duncan taraf 5\% dapat dilihat pada Tabel 8.

Data Tabel 8 menunjukkan bahwa varietas Situ Bagendit menghasilkan jumlah anakan produktif terbanyak dan berbeda nyata dengan kedua varietas uji lainnya, sedangkan pemberian pupuk organik kirinyuh menghasilkan jumlah anakan produktif lebih banyak, berbeda nyata dengan tanpa pemberian dan tidak berbeda nyata dengan kedua pupuk organik lainnya. Menurut hasil penelitian Rahayu dan Harjoso (2011) varietas sangat berpengaruh terhadap pertumbuhan karena setiap varietas mempunyai susunan genotipe yang berbeda, sehingga akan menampilkan beragam morfologis maupun fisiologis. 
Tabel 8. Jumlah Anakan Produktif Beberapa Varietas Padi Gogo pada Pemberian Berbagai Pupuk organik

\begin{tabular}{lllll}
\hline \multicolumn{1}{c}{$\begin{array}{c}\text { Pupuk Organik } \\
\text { (10 ton/ha) }\end{array}$} & \multicolumn{3}{c}{ Varietas Padi Gogo } & \multirow{2}{*}{ Rata-rata } \\
\cline { 2 - 3 } & Inpago 8 & Situ Bagendit & Inpago 9 & \\
\hline Tanpa Perlakuan & $-16,13 \mathrm{bc}$ & $15,76 \mathrm{abc}$ & $8,56 \mathrm{~d}$ & $13,48 \mathrm{~b}$ \\
Kompos TKKS & $13,56 \mathrm{bcd}$ & $20,00 \mathrm{ab}$ & $12,63 \mathrm{~cd}$ & $15,40 \mathrm{ab}$ \\
Pukan Ayam & $14,43 \mathrm{bcd}$ & $17,53 \mathrm{abc}$ & $16,66 \mathrm{abc}$ & $16,21 \mathrm{ab}$ \\
Kirinyuh & $16,13 \mathrm{abc}$ & $22,00 \mathrm{a}$ & $14,00 \mathrm{bcd}$ & $17,37 \mathrm{a}$ \\
\hline Rata-rata & $15,06 \mathrm{~b}$ & $18,82 \mathrm{a}$ & $12,96 \mathrm{~b}$ & \\
\hline
\end{tabular}

Angka-angka pada kolom dan baris yang diikuti huruf kecil yang sama berbeda tidak nyata menurut uji jarak berganda Duncan taraf $5 \%$

Pemberian pupuk organik mempengaruhi banyaknya jumlah anakan produktif tanaman padi, pemberian pupuk hijau kirinyuh menghasilkan jumlah anakan produktif yang lebih banyak. Pupuk hijau kirinyuh mengandung unsur Nitrogen dan Kalium yang lebih tinggi dibandingkan pupuk organik lainnya. Siregar (1981) menyatakan unsur $\mathrm{N}$ berperan penting sebagai penyusun protein yang akan digunakan oleh tanaman untuk meningkatkan jumlah malai perumpun, anakan produktif dan berat gabah perumpun.

Unsur $\mathrm{K}$ yang terkandung dalam tanaman berperan sebagai kofaktor enzim dalam translokasi fotosintat sejumlah hara terutama $\mathrm{N}$, mengatur respirasi, transpirasi, aktivasi enzim piruvatkinase yang berperan dalam sintesis karbohidrat, mengatur tekanan osmotik. Hafsiah et al. (2008) menyatakan unsur $\mathrm{K}$ dapat memperbaiki kualitas tanaman, membantu translokasi fotosintat, meningkatkan resistensi tanaman terhadap hama dan penyakit, sehinggan menjadikan tanaman padi menghasilkan gabah yang lebih bernas dan menurunkan persentase gabah hampa.

\section{Berat Gabah Bernas}

Hasil sidik ragam menunjukkan bahwa beberapa varietas padi gogo dan pemberian berbagai pupuk organik berpengaruh nyata terhadap berat gabah bernas. Hasil uji jarak berganda Duncan taraf 5\% dapat dilihat pada Tabel 9.

Tabel 9. Berat Gabah Bernas per tanaman Beberapa Varietas Padi Gogo pada Pemberian Berbagai Pupuk Organik

\begin{tabular}{|c|c|c|c|c|}
\hline \multirow{2}{*}{$\begin{array}{l}\text { Pupuk Organik } \\
\text { (10 ton/Ha) }\end{array}$} & \multicolumn{3}{|c|}{ Varietas Padi Gogo } & \multirow[t]{2}{*}{ Rata-rata } \\
\hline & Inpago 8 & Situ Bagendit & Inpago 9 & \\
\hline \multicolumn{5}{|c|}{--------------------------------gram------------------------------------ } \\
\hline Tanpa Perlakuan & $1,33 \mathrm{ef}$ & $1,46 \mathrm{def}$ & $0,87 \mathrm{f}$ & $1,22 \mathrm{~b}$ \\
\hline Kompos TKKS & $1,51 \mathrm{def}$ & $2,47 \mathrm{ab}$ & $1,73 \mathrm{cde}$ & $2,04 \mathrm{a}$ \\
\hline Pukan Ayam & $2,30 \mathrm{abc}$ & $2,89 \mathrm{a}$ & $2,23 a b c$ & $2,16 \mathrm{a}$ \\
\hline Kirinyuh & $2,29 a b c$ & $2,05 \mathrm{bcd}$ & $2,09 \mathrm{bcd}$ & $1,92 \mathrm{a}$ \\
\hline Rata-rata & $1,72 \mathrm{~b}$ & $2,22 \mathrm{a}$ & $1,56 \mathrm{~b}$ & \\
\hline
\end{tabular}

Data Tabel 9 menunjukkan bahwa varietas Situ Bagendit mengasilkan berat gabah bernas lebih tinggi dibandingkan dengan varietas Inpago 8 dan Inpago 9, sedangkan pemberian berbagai pupuk organik menghasilkan berat gabah bernas yang berbeda nyata dengan tanpa perlakuan pupuk organik.
Hal ini menunjukkan varietas mempengaruhi hasil dari suatu tanaman dan varietas unggul dapat memberikan hasil yang lebih baik. Berat gabah bernas merupakan komponen hasil yang ditentukan oleh pertumbuhan tanaman, dimana semakin baik pertumbuhan suatu varietas maka akan memberikan hasil yang lebih baik. 
Diantara ketiga varietas uji, varietas Situ Bagendit merupakan varietas yang menghasilkan jumlah anakan maksimum lebih banyak, umur keluar malai lebih cepat dan jumlah anakan produktif yang lebih banyak. Hal ini sesuai dengan pendapat Sarief (1986), bahwa jumlah gabah yang terbentuk pada setiap malai ditentukan pada fase vegetatif.

Pemberian pupuk organik ke dalam tanah diantara tegakan tanaman sawit sangat menguntungkan karena dapat memperbaiki sifat fisik tanah, memperbaiki struktur tanah, meningkatkan porositas dan ketersediaan air sehingga tanah yang tadinya kering dan keras menjadi gembur. Hal ini terlihat dari data yang diperoleh bahwa pemberian bahan organik meningkatkan berat gabah bernas dibandingkan tanpa bahan organik. Pembentukan gabah bernas dipengaruhi oleh ketersediaan nutrisi di dalam tanah.Hal ini terlihat dari data yang diperoleh bahwa pemberian bahan organik meningkatkan berat gabah bernas dibandingkan tanpa bahan organik. Pembentukan gabah bernas dipengaruhi oleh ketersediaan nutrisi di dalam tanah.

Hakim et al. (1986) menyatakan bahwa kekurangan fosfor dapat mengakibatkan perkembangan akar terhambat, terhambatnya pembentukkan bunga, dan penurunan jumlah biji. Ketersediaan unsur hara $\mathrm{P}$ diduga disumbangkan dari pemberian bahan organik, baik berupa kompos TKKS, pukan ayam, dan krinyuh yang merupakan perlakuan dalam penelitian ini. Ketersediaan unsur hara dapat menyumbangkan nutrisi bagi tanaman padi, sehingga berpengaruh terhadap peningkatan hasil.

\section{Persentase Gabah Bernas}

Hasil sidik ragammenunjukkan bahwa beberapa varietas padi dan pemberian berbagai pupuk organik berpengaruh nyata terhadap persentase gabah bernas. Hasil uji jarak berganda Duncan taraf 5\% dapat dilihat pada Tabel 10.

Tabel 10. Persentase Gabah Bernas Beberapa Varietas Padi Gogo pada Pemberian Berbagai Pupuk Organik

\begin{tabular}{lllll}
\hline \multicolumn{1}{c}{ Pupuk Organik } & \multicolumn{3}{c}{ Varietas Padi Gogo } & Rata-rata \\
\cline { 2 - 3 } & \multicolumn{1}{c}{ Inpago 8} & Situ Bagendit & Inpago 9 & \\
\hline \multirow{2}{*}{ Tanpa Perlakuan } & $72,66 \mathrm{~d}$ & $77,00 \mathrm{c}$ & $74,06 \mathrm{~cd}$ & $74,57 \mathrm{~b}$ \\
Kompos TKKS & $80,33 \mathrm{~b}$ & $83,86 \mathrm{a}$ & $81,06 \mathrm{ab}$ & $81,75 \mathrm{a}$ \\
Pukan Ayam & $82,76 \mathrm{ab}$ & $84,90 \mathrm{a}$ & $80,40 \mathrm{ab}$ & $82,68 \mathrm{a}$ \\
Kirinyuh & $81,36 \mathrm{ab}$ & $82,13 \mathrm{ab}$ & $82,66 \mathrm{ab}$ & $82,05 \mathrm{a}$ \\
\hline Rata-rata & $79,03 \mathrm{~b}$ & $81,72 \mathrm{a}$ & $79,55 \mathrm{~b}$ & \\
\hline
\end{tabular}

Angka-angka pada kolom dan baris yang diikuti huruf kecil yang sama berbeda tidak nyata menurut uji jarak berganda Duncan taraf 5\%

Tabel 10 menunjukkan bahwa varietas Situ Bagendit menghasilkan persentase gabah bernas tertinggi dan berbeda nyata dengan varietas Inpago 8 dan Inpago 9 yaitu 81,72\%, sedangkan pemberian berbagai pupuk organik tidak berbeda nyata sesamanya, tetapi berbeda nyata dengan tanpa pemberian bahan organik. Hal ini menunjukkan bahwa varietas Situ Bagendit dalam pengisian bulir lebih maksimal dibandingkan kedua varietas yang diuji.

Pupuk organik menambah ketersediaan unsur hara di dalam tanah, peningkatan $\mathrm{pH}$, memperbaiki aerase dan drainase sehingga unsur hara tersedia dan dapat diserap tanaman padi untuk membantu proses metabolisme, diantaranya pembentukan gabah, serta peningkatan translokasi asimilat ke gabah.

Unsur hara $\mathrm{N}, \mathrm{P}$ dan $\mathrm{K}$ merupakan komponen yang dapat diserap cepat selama pertumbuhan vegetatif dan ditranslokasikan dari jaringan vegetatif dan dimanfaatkan tanaman untuk mempercepat proses metabolisme tanaman sehingga pertumbuhan dan perkembangan tanaman meningkat. Sumekto (2008) menyatakan bahwa fosfor yang diberi pada tanaman berfungsi mempercepat pertumbuhan akar semai, memperkuat pertumbuhan tanaman muda dan 
meningkatkan produksi biji-bijian seperti pengisian gabah. Pemberian Nitrogen pada tanaman berfungsi mempercepat, tinggi tanaman, jumlah anakan dan jumlah cabang (Soepardi, 1983).

\section{Berat 1000 Biji}

Tabel 11. Berat 1000 biji Beberapa Varietas Padi Gogo pada Pemberian Berbagai Pupuk Organik.

\begin{tabular}{llcll}
\hline \multicolumn{1}{c}{ Pupuk Organik } & \multicolumn{3}{c}{ Varietas Padi Gogo } & Rata-rata \\
\cline { 2 - 3 } \multicolumn{1}{c}{ (10 ton/ha) } & Inpago 8 & S itu Bagendit & Inpago 9 & \\
\hline Tanpa Perlakuan & $21,46 \mathrm{ef}$ & $21,53 \mathrm{ef}$ & $21,26 \mathrm{f}$ & $21,42 \mathrm{~b}$ \\
Kompos TKKS & $22,70 \mathrm{bcd}$ & $23,90 \mathrm{a}$ & $22,53 \mathrm{~cd}$ & $23,04 \mathrm{a}$ \\
Pukan Ayam & $22,86 \mathrm{bcd}$ & $24,20 \mathrm{a}$ & $23,50 \mathrm{ab}$ & $23,52 \mathrm{a}$ \\
Kirinyuh & $23,30 \mathrm{abc}$ & $23,50 \mathrm{ab}$ & $22,30 \mathrm{de}$ & $23,03 \mathrm{a}$ \\
\hline Rata-rata & $22,58 \mathrm{~b}$ & $23,28 \mathrm{a}$ & $22,40 \mathrm{~b}$ & \\
\hline
\end{tabular}

Angka-angka pada kolom dan baris yang diikuti huruf kecil yang sama berbeda tidak nyata menurut uji jarak berganda Duncan taraf 5\%

Tabel 11 menunjukkan bahwa varietas Situ Bagendit menghasilkan berat 1000 biji tertinggi yaitu 23,28 gram dan berbeda nyata dengan varietas Inpago 8 dan Inpago 9, sedangkan pemberian berbagai pupuk organik tidak berbeda nyata sesamanya, tetapi berbeda nyata dengan tanpa pemberian pupuk organik. Hal ini menunjukkan bahwa varietas Situ Bagendit mempunyai kemampuan adaptasi yang baik dengan lingkungan tumbuh di antara tegakan tanaman kelapa sawit.

Varietas Situ Bagendit memperlihatkan pertumbuhan generatif yang lebih baik dibandingkan dengan 2 varietas uji lainnya. Kim et al. (2011) menyatakan bahwa penurunan bobot gabah dapat dipengaruhi oleh suhu udara yang tinggi yang memicu berkurangnya aktivitas source dan sink serta
Hasil sidik ragam menunjukkan bahwa beberapa varietas padi dan pemberian berbagaipupuk organik berpengaruh nyata terhadap berat 1000 biji. Hasil uji jarak berganda Duncan taraf 5\% dapat dilihat pada Tabel 11.

Tabel 12. Berat Gabah Kering Giling (Per plot) Beberapa Varietas Padi Gogo pada Pemberian Berbagai Pupuk Organik

\begin{tabular}{lllll}
\hline \multirow{2}{*}{\begin{tabular}{c} 
Pupuk Organik \\
\multicolumn{1}{c}{10 ton/ha) }
\end{tabular}} & \multicolumn{3}{c}{ Varietas Padi Gogo } & \multirow{2}{*}{ Rata-rata } \\
\cline { 2 - 3 } & Inpago 8 & Situ Bagendit & Inpago 9 & \\
\hline Tanpa Perlakuan & $541,00 \mathrm{e}$ & $578,33 \mathrm{de}$ & $542,00 \mathrm{e}$ & \\
Kompos TKKS & $607,00 \mathrm{~cd}$ & $683,67 \mathrm{~b}$ & $594,67 \mathrm{~cd}$ & $643,78 \mathrm{~b}$ \\
Pukan Ayam & $637,33 \mathrm{c}$ & $738,67 \mathrm{a}$ & $610,00 \mathrm{~cd}$ & $662,22 \mathrm{a}$ \\
Kirinyuh & $609,00 \mathrm{~cd}$ & $682,67 \mathrm{~b}$ & $615,00 \mathrm{~cd}$ & $635,56 \mathrm{a}$ \\
\hline Rata-rata & $598,58 \mathrm{~b}$ & $670,83 \mathrm{a}$ & $590,41 \mathrm{~b}$ & \\
\hline
\end{tabular}

Angka-angka pada kolom dan baris yang diikuti huruf kecil yang sama berbeda tidak nyata menurut uji jarak berganda Duncan taraf 5\% 
Tabel 12 menunjukkan bahwa varietas Situ Bagendit menghasilkan berat gabah kering giling tertinggi yaitu 670.83 gram setara dengan 4,16 ton/ha dan berbeda nyata dengan varietas Inpago 8 dan Inpago 9, sedangkan pemberian pupuk organik tidak memperlihatkan berat gabah kering giling secara nyata tetapi berbeda nyata dengan tanpa perlakuan. Kombinasi pemberian pukan ayam pada varietas Situ Bagendit menunjukkan berat gabah kering giling tertinggi yaitu 738,67 gram setara dengan 4,6 ton/ha dan berbeda nyata dengan semua perlakuan.

Hal ini menunjukkan bahwa varietas Situ Bagendit beradaptasi dengan baik pada lingkungan diantara tegakan tanaman kelapa sawit belum menghasilkan sehingga dapat menyerap unsur hara dan nutrisi dengan baik, varietas Situ Bagendit memiliki genetik yang mampu beradaptasi sehingga memperlihatkan pertumbuhan vegetatif dan generatif yang baik dibandingkan dengan kedua varietas uji lainnya. Kondisi tanah yang lebih baik mampu memperbaiki pH dan KTK tanah (Tabel 1). Unsur nitrogen dan fosfot yang terkandung pada pukan ayam mampu merangsang pertumbuhan akar sehingga meningkatkan kapasitas serapan dan kecepatan penyerapan hara $\mathrm{P}$, sehingga fotosintesis juga akan meningkat dan fotosintat yang dihasilkan juga semakin besar sehingga berat kering dalam biji semakin besar.

\section{KESIMPULAN}

Berdasarkan hasil penelitian disimpulkan bahwa :

1. Beberapa varietas padi gogo memiliki respon yang berbeda terhadap pemberian berbagai jenis pupuk organik. Varietas Situ Bagendit merupakan varietas yang mempunyai respon paling baik dibanding dua varietas uji lainnya, terlihat pada setiap parameter pengamatan kecualiparameter tinggi tanaman.

2. Pemberian berbagai jenis pupuk organik 10 ton/ha berpengaruh terhadap umur keluar malai, namun tidak berpengaruh nyata terhadap tinggi tanaman, jumlah anakan maksimum, jumlah anakan produktif, berat gabah bernas, persentase gabah bernas, berat 1000 biji dan berat gabah kering gilingdibandingkan dengan tanpa pemberian pupuk organik.

3. Varietas Situ Bagendit menghasilkan berat gabah kering giling tertinggi yaitu 4,6 ton/ha pada pemberian pukan ayam.

\section{DAFTAR PUSTAKA}

Hafsiah, M. Taufik, T. Wijayanto. 2008. Uji daya hasil dan ketahanan padi gogo lokal terhadap penyakit blas (Pyricularia oryzae) pada berbagai dosis pemupukan. Berkala Penelitian Agronomi. Kendari. Vol 1. No 1. Hal. 26-36.

Hakim, N., Nyakpa, A. M. Lubis, S.G Nugroho, M.R. Saul, M.A Diha, G.B. Hong dan H.H.Barley. 1986. DasarDasar Ilmu Tanah. Universitas Lampung. Lampung.

Haris A. 1999. Karakteristik Iklim Mikro dan Respon Tanaman Padi Gogo pada Pola Tanam Sela dengan Tanaman Karet (Tesis). Bogor : Program Pascasarjana, Institut Pertanian Bogor.

Kamil. J. 1986. Teknologi Benih 1. Angkasa Raya. Padang.

Kim, J., Choi, Y., Lee, S.H., Koh, Y.H. 2011. Genotype variation for toleran to phosphorus deficiency in rice and the potential for its exploitation in rice improvement. New York.

Lingga, P. 1991. Jenis dan Kandungan Hara pada Beberapa Kotoran Ternak. Raja grafindo Persada. Jakarta.

Nyakpa, Y.M., A.A. Lubis, M.A. Pulung, A.G. Amrah, A. Munawar, Go Ban Hong dan N. Hakim. 1988. Kesuburan tanah. Universitas Lampung Press.

Oldeman, L.R and M.Prere. 1982. A Study of the a agroclimatology of the humid tropic South East Asia. IRRI. Philippines.

Rahayu, A. Y, dan Harjoso, T. 2011. Aplikasiabu sekam pada padi gogo (Oryza sativa L.) terhadap kandungan silikat dan prolin daun serta amilosa dan protein biji. Jurnal volume 16 (1): 4855.

Sarief, E. S. 1986. Kesuburan dan Pemupukan Tanah Pertanian. Pustaka Buana. Bandung. 
Siregar. 1981. Pengaruh pupuk NPK terhadap peningkatan produksi padi gogo. Jurnal Balai Pengkajian Teknologi Pertanian Jawa Barat. Volume 2 (1) : 55-61.

Soepardi, G. 1983. Sifat dan Ciri Tanah. Fakultas Pertanian Institut Pertanian Bogor. Bogor.

Soepardi, G. 1983. Sifat dan Ciri Tanah. Fakultas Pertanian Institut Pertanian Bogor. Bogor.

Sumekto, R. 2008. Kesuburan Tanah. Pustaka Buana. Bandung.

Tejasuwarna, 1999. Pengaruh pupuk kandang terhadap hasil wortel dan sifat fisik tanah. Konggres Nasional VII. HITI. Bandung, 2-4 Nopember 1999.

Yoshida, S. 1981. Fundamental of Rice Crop Science. Los Banos. Philippines.

Yoshida, S., and F.T. Parao. 1976. Climate influence on yield and yield components of lowland rice in the tropincs. Proceeding symposium on climate and rice. IRRI. The int. Rice. Res. Inst. Las Banos Philippines. 
Pemberian berbagai Pupuk Organik terhadap Pertumbuhan dan Produksi Beberapa Varietas Padi Gogo (Oryza sativa L.) yang di Tanam diantara Tanaman Kelapa Sawit Belum Menghasilkan 